\title{
Strategi Pengembangan Industri Kecil Bakso Di Kecamatan Loceret Kabupaten Nganjuk
}

\author{
Witri Januarista \\ Magister Agribisnis Universitas Islam Kadiri
}

\begin{abstract}
Abstrak
Penelitian ini dilaksanakan pada Industri Kecil Bakso di 3 (tiga) Desa yaitu Desa Loceret, Desa Bajulan dan Desa Jatirejo Kecamatan Loceret Kabupaten Nganjuk Propinsi Jawa Timur, mulai 15 Maret - 15 Mei 2017. Tujuan Penelitian ini adalah untuk : menganalisis faktor-faktor strategis; mendeskripsikan strategi permodalan, produksi, pengembangan Sumber Daya Manusia dan Pemasaran; merumuskan alternatif strategi dan menentukan prioritas strategi apa yang dapat diterapkan dalam pemasaran Industri kecil bakso di Kecamatan Loceret Kabupaten Nganjuk. Diharapkan hasil penelitian ini dapat menambah wawasan dan pengetahuan peneliti tentang permasalahan yang dikaji; dapat menjadi sumbangan pemikiran dan bahan pertimbangan dalam menyusun kebijakan yang lebih baik di masa yang akan datang, terutama dalam strategi permodalan, produksi, pengembangan Sumber Daya Manusia dan Pemasaran pada industri kecil bakso yang digunakan.

Materi yang digunakan dalam penelitian ini adalah seluruh industri kecil bakso di 3 (tiga) Desa yaitu Desa Loceret, Desa Bajulan dan Desa Jatirejo Kecamatan Loceret Kabupaten Nganjuk Propinsi Jawa Timur sebanyak 43 responden dari 127 industri keci bakso di Kecamatan Loceret Kabupaten Nganjuk. Pengambilan sampel sumber data dilakukan secara purposive dan snowbaal, teknik pengumpulan data dengan menggunakan triangulasi (gabungan) melalui Wawancara atau interview, Observasi dan Pencatatan. Data yang dikumpulkan terdiri dari data primer dan data sekunder. Analisis data bersifat induktif/kualitatif melalui : (a) Analisis Faktor Internal dan Eksternal usaha kecil bakso dengan Matrik External Factors Evaluation (EFE) dan Matrik Internal Factors Evaluation (IFE) (b) Analisis Posisi usaha kecil bakso dengan Matrik Internal External (IE) (c) Analisis SWOT dan (d) Menentukan Prioritas Strategi dengan Matrik QSP (Quantitative Strategic Planning Matrix/Matrik Perencanaan Strategis Kuantitatif)

Hasil penelitian menunjukkan bahwa (1) Strategi produksi industri kecil bakso adalah bahan baku yang digunakan merupakan bahan baku yang kualitasnya sedang, pembuatan bumbu sangat diperhatikan agar mendapatkan cita rasa yang khas dan tidak berubah - ubah dalam setiap produksi, tempat produksi bakso berada dibelakang/dapur rumah produsen, penggunaan tenaga kerja yang sudah terampil dalam proses produksi bakso, pemilik industri kecil bakso ikut serta dalam proses produksi; (2) Strategi pemasarannya adalah harga jual yang murah, peningkatan penjualan pada saat mendapatkan pesanan untuk acara tertentu dengan di barengi ciri khas dan cita rasa yang dimiliki para pedagang bakso, Promosi dengan mengaktifkan kembali koperasi untuk menaungi kebutuhan para pedagang bakso baik dari segi produksi maupun pemasaran, memanfaatkan peluang pemasaran hingga ke luar kota dengan angkatan tenaga kerja muda yang merantau; (3) Strategi pengembangan sumber daya manusia (tenaga kerja) yaitu, tenaga kerja yang sudah berpengalaman mengajarkan keterampilan dalam membuat bakso kepada angkatan kerja yang sudah siap untuk bekerja, sudah adanya rencana pengaktifkan kembali paguyuban industri bakso yang sempat berhenti dengan suatu alasan tertentu, adanya tambahan tenaga kerja dari luar daerah dalam industri kecil bakso, pemberian upah tambahan atau bonus bagi tenaga kerja yang bekerja dengan giat; (4) Sedangkan strategi permodalannya adalah, Modal awal berasal dari modal sendiri dan kurangnya kesadaran akan pentingnya pembukuan keuangan.

Kata Kunci : Strategi Pengembangan, Industri Kecil, Industri Bakso
\end{abstract}

\section{Pendahuluan}

Sektor industri diyakini sebagai sektor yang dapat memimpin sektor-sektor lain dalam sebuah perekonomian menuju kemajuan. Produk-produk industrial selalu memiliki dasar tukar (terms of trade) yang 
tinggi atau lebih menguntungkan serta menciptakan nilai tambah yang lebih besar dibandingkan produk-produk sektor lain. $\mathrm{Hal}$ ini disebabkan karena sektor industri memiliki variasi produk yang sangat beragam dan mampu memberikan manfaat marginal yang tinggi kepada pemakainya (Dumairy, 1996).

Usaha Mikro Kecil Menengah (UMKM) berpotensi menjadi motor penggerak perekono-mian nasional aatara lain karena : (1) Jumlah unit usaha besar (99\%); (2) Penyerapan tenaga kerja (99\%); (3) Sumbangan kepada PDB (57\%); (4) Mempunyai ketahanan terhadap krisis yg relatif lebih baik dibanding usaha besar; (5) Kredit UMKM menjadi salah satu upaya penyebaran risiko bank dan (6) Reputasi kredit UMKM cukup baik. (https: //id.wikipedia.org/wiki/UsahaKecilMenenga h)

Pengembangan industri pengolahan pangan di Indonesia yang didukung oleh sumberdaya alam pertanian, baik nabati maupun hewani mampu menghasilkan berbagai produk olahan yang dapat dibuat dan dikembangkan dari sumber daya alam lokal atau daerah. Saat ini di beberapa negara Asia banyak produk pangan yang diangkat dari jenis pangan lokal dan diolah secara tradisional. Dengan berkembangnya produk lokal tersebut, maka jumlah dan jenis produk pangan menjadi semakin banyak jumlahnya (Soleh, 2010).

Usaha pengolahan bakso daging merupakan pemanfaatan produk peternakan yang mengolah hasil daging menjadi produk bakso yang bernilai lebih tinggi serta meningkat pula kemanfaatannya. Bakso adalah campuran homogen daging, tepung pati dan bumbu yang telah mengalami proses ekstrusi dan pemasakan. Cara pembuatan bakso, yang pertama adalah daging digiling hingga menjadi halus, kemudian dicampur dengan tepung dan bumbu di dalam alat pencampur khusus sehingga bahan tercampur menjadi bahan adonan yang sangat rata dan halus. Setelah itu adonan dicetak berbentuk bulat dan direbus sampai matang. Bakso yang bermutu bagus dapat dibuat tanpa penambahan bahan kimia apapun. Usaha Kecil Bakso di Kecamatan Loceret Kabupaten Nganjuk merupakan salah satu usaha kecil yang menjalankan usaha mem-produksi bakso dan menjalankan pemasaran dengan gerobak keliling.

Untuk menjadi pemenang dalam persaingan yang kompetitif bukan hal yang mudah, mengingat usaha kecil harus mempunyai langkah-langkah sendiri agar lebih unggul dibandingkan dengan pesaingnya. Bukan hanya unggul dalam hal kualitas produk tetapi juga dalam hal pemasaran. Oleh karena itu, diperlukan suatu perumusan tentang strategi pemasaran yang tepat demi kelangsungan hidup bagi usaha kecil tersebut. Permasalahan klasik yang terjadi pada industri kecil bakso adalah berbagai permasalahan seperti permodalan, teknologi, pemasaran, akses informasi pasar dan adanya kesalahan seperti kesalahan perencanaan, kesalahan dalam menaksir pasar, kesalahan dalam memperkirakan kontinuitas bahan baku dan sebagainya. Dengan berbagai permasalahan dan kelemahan itu industri kecil bakso dapat mengalami resiko kegagalan yang dapat menyebabkan kebangkrutan.

Dengan semakin melambungnya harga daging sapi dan ayam serta bahan baku penunjang lainnya seperti bumbu, mengakibat-kan adanya variasi teknis pengolahan dan pemasarannya. Di sisi lain, ekspansi dari perusahaan besar yang memiliki produk bakso daging dalam kemasan modern, turut meng-hambat perkembangan usaha pengolahan bakso daging serta pemasaranya masih kalah bersaing dengan produk bakso daging dari perusahaan besar yang lebih dikenal masyarakat.

Penelitian ini berusaha menemukan faktor-faktor strategis, strategi, alterntif strategi dan prioritas strategi permodalan, produksi, pengem-bangan Sumber Daya Manusia dan Pemasaran pada industri kecil bakso di Kecamatan Loceret Kabupaten Nganjuk Jawa Timur.

\section{Metode Penelitian}

Penelitian ini dilaksanakan pada Industri Kecil Bakso di 3 (tiga) Desa yaitu 
Desa Loceret, Desa Bajulan dan Desa Candirejo Kecamatan Loceret Kabupaten Nganjuk Propinsi Jawa Timur, pada 15 Maret - 15 Mei 2017.

Materi yang digunakan dalam penelitian ini adalah Industri Kecil Bakso yang meliputi kondisi SDM, modal, teknologi, bahan baku, dan pemasaran; permasalahan industri kecil bakso; serta strategi pengembangan industri bakso yang dirumuskan menjadi strategi produksi, pemasaran, SDM (Tenaga Kerja) dan permodalan di 3 (tiga) Desa yaitu Desa Loceret, Desa Bajulan dan Desa Candirejo Kecamatan Loceret Kabupaten Nganjuk Propinsi Jawa Timur.

Penelitian ini menggunakan jenis penelitian kualitatif. Penentuan lokasi penelitian dilakukan dengan sengaja (purposive), yaitu lokasi penelitian yang dipilih dengan sengaja karena alasanalasan tertentu yang disesuaikan dengan tujuan penelitian. Tujuan dari penelitian yaitu mendeskripsikan dan analisis strategi pengembangan industri kecil bakso dan populasi di Kecamatan Loceret Kabupaten Nganjuk Propinsi Jawa Timur.Teknis pelaksanaan penelitian ini dilaksanakan dengan teknik survey, yaitu cara pengumpulan data dari sejumlah unit atau individu dalam waktu (atau jangka waktu) yang bersamaan (Suparmoko, 2009).

\section{Populasi dan Sampel}

Populasi pedagang bakso yang ada di Kecamatan Loceret Kabupaten Nganjuk pada tahun 2017 yaitu 127 orang. Pada penelitian ini, informan yang akan diambil yaitu seluruh pedagang bakso di 3 (tiga) Desa yaitu Desa Loceret, Desa Bajulan dan Desa Candirejo Kecamatan Loceret Kabupaten Nganjuk yang berjumlah 43 orang.

Pengambilan sampel sumber data dilakukan secara purposive dan snowbaal, teknik pengumpulan data dengan menggunakan triangulasi (gabungan), analisis data bersifat induktif/kualitatif, dan hasil dari penelitian kualitatif lebih menekankan makna dari pada generalisasi (Sugiyono, 2012).

Pengambilan informan juga dilakukan dari Perangkat desa serta Dinas yang terkait bertujuan karena untuk mendapatkan data sekunder mengenai industri kecil bakso selain itu juga karena dianggap sebagai paling tahu atau sebagai penguasa sehingga akan memudahkan penelitian ini.

Faktor strategis merupakan bahan untuk pembuatan quesioner rating dan pembobotan. Quesioner tersebut diwawancarakan kepada keys informan yang dipilih secara purposive yang terdiri dari pemimpin/pemilik Industri Kecil Bakso, karyawan produksi, penjual bakso keliling, pemasok, konsumen produk bakso, pemimpin Industri pesaing, konsumen Industri pesaing, dan pemerintah daerah. Dalam wawancara tersebut, responden memberikan bobot dan rating terhadap faktor strategis yang diuraikan di dalam quesioner.

Jenis data yang dibutuhkan dalam penelitian ini berdasarkan sumbernya adalah data primer dan data sekunder. Data primer yang diperoleh pada penelitian ini adalah dengan hasil kuesioner dan wawancara secara langsung dengan berbagai pihak yang telah dipilih menjadi sampel atau responden terkait dengan kegiatan Industri Kecil bakso, baik dengan menggunakan kuesioner maupun tanpa menggunakan kuesioner. Sumber data sekunder dalam penelitian ini adalah data yang diperoleh dari Desa, Dinas/ Instansi terkait. Data sekunder tersebut meliputi data keadaan umum Industri Kecil, data permodalan, produksi dan penjualan produk, dan data lain yang relevan.

\section{Variabel Penelitian}

Variabel dalam penelitian ini adalah 1 . Kondisi yang ada dalam produksi Industri Kecil Bakso dan 2. Strategi pengembangan Industri Kecil Bakso

Kondisi yang ada dalam produksi Industri Kecil Bakso meliputi : $A$. SDM (Tenaga Kerja) dengan indikator (1) Jumlah dan usia tenaga kerja (2) Tingkat pendidikan (3) Status tenaga kerja dan (4) Tingkat upah; $B$. Modal dengan indikator (1) Penggunaan modal operasional (2) Sumber modal dan (3) Manajemen keuangan; C. Pemasaran dengan indikator (1) Cara pemasaran, (2) Harga, 
(3) Metode promosi (4) Daerah pemasaran. Dan (5) Strategi Pemasaran; D. Bahan Baku dengan indikator (1) Bahan baku/produksi (2) Asal bahan baku (3) Kualitas bahan baku (4) Harga bahan baku (5) Lama waktu produksi dan (6) Kualitas produksi; E. Teknologi dengan indikator (1) Teknologi yang digunakan (2) Alat produksi dan (3) Proses produksi.

Strategi pengembangan Industri Kecil Bakso khususnya aspek perencanaan pengembangan, meliputi : (1) Strategi produksi dan pengolahan (Bahan Baku Alat dan Tempat Produksi - Proses Produksi Bakso - Kemampuan Produksi Produk Baru Yang Dikembangkan); (2) Strategi Pemasaran (Produk dan Harga yang Dipasarkan-Teknik PemasaranDaerah Pemasaran); (3) Strategi SDM /Tenaga Kerja ( Perencanaan SDM (Tenaga Kerja) - Tingkat PendidikanPembagian Tugas Tenaga Kerja Ketrampilan Tenaga Kerja - Upaya Meningkatkan Kesejahteraan Tenaga Kerja) dan (4) Strategi Permodalan. (Sumber Modal-Sistem Pengelolaan Keuangan - Bantuan Modal).

\section{Analisis Data}

Analisis data bersifat induktif/kualitatif melalui : (a) Analisis Faktor Internal dan Eksternal usaha kecil bakso dengan Matrik External Factors Evaluation (EFE) dan Matrik Internal Factors Evaluation (IFE) (b) Analisis Posisi usaha kecil bakso dengan Matrik Internal External (IE) (c) Analisis SWOT dan (d) Menentukan Prioritas Strategi dengan Matrik QSP (Quantitative Strategic Planning Matrix/Matrik Perencanaan Strategis Kuantitatif)

\section{Hasil Dan Pembahasan}

Industri Pengolahan di Kabupaten Nganjuk dikelompokkan ke dalam 4 (empat) golongan berdasarkan banyaknya pekerja yaitu :

a. Industri Besar adalah perusahaan yang mempunyai pekerja 100 orang atau lebih.

b. Industri Sedang adalah perusahaan yang mempunyai pekerja 20-99 orang. c. Industri Kecil adalah perusahaan yang mempunyai pekerja 5-19 orang.

d. Industri Rumahtangga adalah usaha kerajinan rumah tangga yang mempunyai pekerja 1-4 orang. (http:// nganjukkab.bps.go.id; Dinas Perdagangan, Industri dan Koperasi Kabupaten Nganjuk Tahun 2016)

Industri kecil menurut kelompok dibagi menjadi formal dan non formal. Unit usaha formal sebanyak 1.146 unit dan non formal 15.299 unit, menyerap tenaga kerja sebanyak 17.185 orang dan 43.833 orang. Industri Kecil Bakso pada umumnya merupakan industri Kecil Non Formal, hal ini didasarkan bahwa sebagian besar usaha kecil ini termasuk dalam industri pengolahan milik sendiri dan tidak memiliki ijin usaha secara resmi (tidak memiliki TDP).

Perkembangan Industri Kecil Bakso di Kecamatan Loceret Kabupaten Nganjuk yang sudah lama tidak terlepas dari adanya UD. "Candi Baru" terletak di JI, Raya Kediri No. 99 Desa Loceret Kecamatan Loceret Kabupaten Nganjuk, yang salah satu usahanya adalah melakukan Penjualan dan Pengolahan daging hasil pemotongan ternak sapi yang menggunakan sistem daging "ASUH" yaitu AMAN, SEHAT, UTUH DAN HALAL.

\section{Identifikasi Faktor Internal dan Eksternal}

\section{(1) Identifikasi Faktor Internal}

Identifikasi faktor internal perusahaan merupakan proses identifikasi faktor-faktor internal yang berada di perusahaan, meliputi proses produksi dan teknologi; pemasaran; sumber daya manusia perusahaan dan Modal.

Hasil identifikasi tentang SDM diketahui bahwa Sumberdaya manusia/ karyawan yang terlibat dalam produksi pengolahan bakso.rata-rata berjumlah \pm 8,77 orang/unit usaha yang terbagi menjadi 3, yaitu pekerja tetap, pekerja sampingan atau borongan dan pekerja keluarga yang tidak dibayar. Jadwal kerja tetap mulai hari Senin sampai hari Jum'at pukul 07.00-15.00 WIB dan pada hari Sabtu pukul 07.00-13.00 WIB. 
Hasil identifikasi tentang Teknologi diketahui bahwa Industri kecil bakso di Kecamatan Loceret Kabupaten Nganjuk sebagian sudah.menggunakan peralatan yang menggunakan mesin, yaitu mesin penggiling daging, mesin pencampur adonan, mesin pencetak bakso, dan juga freezer/lemari pendingin. Namun sebagian besar khususnya mesin penggiling daging masih sewa.

Hasil identifikasi tentang produksi diketahui bahwa Bakso daging yang dihasilkan merupakan hasil pencampuran daging sapi dengan daging ayam dengan perbandingan setiap $3 \mathrm{~kg}$ daging sapi dicampur dengan $2 \mathrm{~kg}$ daging ayam atau sejumlah $5 \mathrm{~kg}$ dalam sekali proses produksi. Bakso dicetak dengan menggunakan mesin pencetak bakso maupun manual dengan diameter $2,5 \mathrm{~cm}$ dan diameter $3 \mathrm{~cm}$. Setelah selesai dicetak, bakso kemudian didinginkan dengan diangin-anginkan di ruang terbuka. Setelah dingin, bakso dikemas dalam kantong plastik.Adapun data produksi bakso bulan Maret 2017 sebagai berikut :

Tabel 1. Data Rata-rata Produksi Bakso (Maret 2017)

\begin{tabular}{|ccc}
\hline Tanggal & $\begin{array}{l}\text { Hasil } \\
\text { (kemasan) }\end{array}$ & $\begin{array}{c}\text { Produksi } \\
\text { Cukso }\end{array}$ \\
\cline { 2 - 3 } Awal & Curah \\
1 & 155 \\
4 & 10 \\
7 & 70 \\
8 & 10 \\
9 & 150 \\
11 & 50 \\
14 & 180 \\
16 & 200 \\
17 & - \\
18 & - \\
19 & - \\
25 & 170 \\
29 & - \\
\hline Jumlah & 70 \\
\hline
\end{tabular}

Sumber: Data primer Produksi Bakso

Hasil identifikasi tentang pemasaran diketahui bahwa Kebijakan segmentasi pasar yang dilakukan atas dasar geografis meliputi wilayah Kabupaten Nganjuk, Jombang dan Madiun, sedangkan atas dasar psikografi diketahui Konsumen yang membeli biasanya adalah konsumen rumah tangga dengan motif pembelian untuk dimanfaatkan dan dikonsumsi secara langsung, oleh-oleh keluarga dan bukan untuk industri. Kebijakan tentang pasar sasaran diketahui bahwa memfokuskan pasar sasarannya pada konsumen rumah tangga dengan menempatkan produknya sebagai produk bakso eceran oleh pedagang keliling yang memiliki harga terjangkau. Differensiasi terkait dengan cara membangun strategi pemasaran di berbagai aspek perusahaan, maka perusahaan melakukan pem-bedaan produk dengan menawarkan produk bakso kemasan eceran melalui pedagang keliling dengan harga yang terjangkau untuk konsumen. Bauran pemasaran dengan aspek produk, harga, distribusi, dan promosi diketahui bahwa selalu berusaha mengoptimalkan dan memberikan jaminan pada kualitas produk bakso daging yang dihasilkan; Harga produk bakso Rp 17.500 untuk pedagang pengecer dan Rp. 20.000 unuk konsuen biasa dalam berat yang sama yaitu \pm 300 gram dalam kemasan 50 butir diameter $3,5 \mathrm{~cm}, 30$ butir diameter $3,5 \mathrm{~cm}$ atau 20 butir diameter $3,5 \mathrm{~cm}$. Distribusi dilakukan dengan 2 cara yaitu Langsung ke konsumen dan melalui pedagang pengecer. Belum ada promosi sistematis dan terintegrasi. Promosi terjadi secara alamiah getok tular oleh konsumen.

\section{(2) Identifikasi Faktor Eksternal}

Identifikasi faktor-faktor eksternal yang berada di perusahaan, meliputi pemasok, konsumen, distributor, pesaing, pemerintah, dan kondisi ekonomi. Pasokan bahan baku daging sapi dan daging ayam diperoleh dari UD Candi Baru Nganjuk. Sapi yang dipotong mayoritas milik usaha peternakan UD Candi Baru yang dipotong di Rumah Potong Hewan (RPH) Kabupaten Nganjuk. Konsumen bakso terdiri dari Konsumen rumah tangga, pedagang pengecer dan pedagang antara yang dititipi produk bakso oleh perusahaan (warung bakso). Balas jasa yang diterima oleh pedagang pengecer atau warung bakso berupa pengurangan harga $12,5 \%$ dari harga 
normal yang ditawarkan perusahaan. Pesaing bagi Industri kecil bakso di Kecamatan Loceret Kabupaten Nganjuk. adalah para produsen bakso daging eceran yang menjual produk bakso daging tanpa kemasan. Pesaing juga berasal dari perusahaan lain yang juga memproduksi produk olahan daging berupa bakso daging dalam kemasan dan bermerk. Pesaing tersebut, berdasarkan survey yang telah dilakukan di pasar swalayan, memiliki merk antara lain, Champ, Fiesta, Bernardi, dan So Good. Produk bakso daging dengan beberapa merek tersebut menjual produk bakso dagingnya ke pasar swalayan dan mini market. Peran pemerintah dilakukan dalam pengenalan produk melalui pameran agribisnis dan kuliner di pusat kota. Kondisi ekonomi masyarakat sekarang yang cukup stabil membawa pengaruh yang positif terhadap jalannya industri bakso daging, terutama terhadap pendapatan yang akan diperoleh. Dengan kondisi ekonomi yang relatif stabil, membuat perusahaan tidak terlalu sulit untuk menentukan harga untuk produknya.

\section{Identifikasi Faktor-Faktor Strategis}

Identifikasi faktor-faktor internal dapat dilihat pada Tabel 2. Sedangkan Identifikasi faktor-faktor eksternal dapat dilihat pada Tabel 3.

Faktor kekuatan yang terdapat di dalam lingkungan internal Industri kecil bakso adalah (1) Pengalaman produksi perusahaan (2) Kemampuan karyawan/ pekerja (3) Kualitas yang terjaga (4) Harga jual yang cukup terjangkau (5) Ciri khas produk dan segmentasi pasar (6) Target pasar untuk semua golongan usia dan (7) Lokasi usaha yang strategis. Sedangkan Fakor kelemahan adalah (1) Kurangnya kemampuan manajerial (2) Keterbatasan modal (3) Kurangnya kemampuan promosi dan (4) Kurangnya akses terhadap informasi.

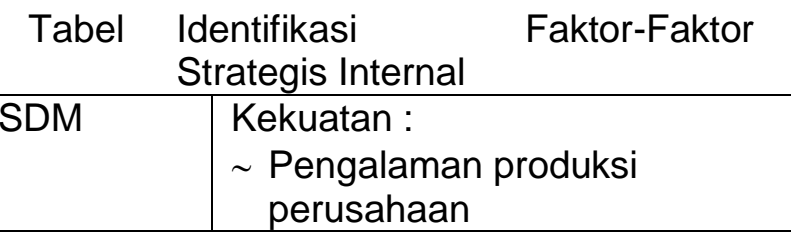

\begin{tabular}{|l|l|}
\hline & Kelemahan \\
& $\sim$ Tenaga pemasaran yang \\
& masih kurang
\end{tabular}

Sumber: Analisis Data Primer

Tabel 3. Identifikasi Faktor-Faktor Strategis Eksternal

\begin{tabular}{|l|l|}
\hline Pemasok & $\begin{array}{l}\text { Peluang } \\
\checkmark \text { Kontinuitas bahan baku } \\
\text { terjamin } \\
\text { Ancaman } \\
\checkmark \text { Tenaga pemasaran yang } \\
\text { masih kurang }\end{array}$ \\
\hline Konsumen & $\begin{array}{l}\text { Peluang } \\
\checkmark \text { Adanya kepercayaan } \\
\text { konsumen } \\
\checkmark \text { Konsumen dari pelanggan } \\
\text { perusahaan }\end{array}$ \\
\hline Distributor & $\begin{array}{l}\text { Peluang } \\
\checkmark \text { Membantu memperluas } \\
\text { pasar }\end{array}$ \\
\hline Pesaing & $\begin{array}{l}\text { Ancaman } \\
\checkmark \text { Semakin banyak produk } \\
\text { bakso tanpa merk di pasaran }\end{array}$ \\
& $\begin{array}{l}\checkmark \text { Merek produk pesaing yang } \\
\text { sudah terkenal }\end{array}$ \\
\hline Pemerintah & $\begin{array}{l}\text { Peluang } \\
\checkmark \text { Mengadakan pameran }\end{array}$ \\
\hline Kondisi & $\begin{array}{l}\text { Peluang } \\
\checkmark \text { Kondisi ekonomi yang relatif } \\
\text { Ekonomi }\end{array}$ \\
\hline
\end{tabular}

Sumber: Analisis Data Primer 
Faktor Peluang yang terdapat di dalam lingkungan Eksternal Industri kecil bakso adalah (1) Kontinuitas bahan baku terjamin, (2) Adanya kepercayaan konsumen (3) Konsumen dari peserta pelatihan atau magang yang diadakan perusahaan

(4) Pedagang pengecer membantu memperluas pasar(5)Adanya pameran yang diadakan pemerintah dan (6) Kondisi ekonomi yang relatif stabil. Sedangkan Fakor Ancaman adalah (1) Semakin banyak produk bakso tanpa merek di pasar dan (2) Merek produk pesaing yang lebih terkenal

\section{Analisis Penentuan Alternatif Strategi}

\section{Internal Faktor Evaluation Matrix (Matriks} IFE)

Hasil Matriks IFE menunjukkan bahwa kekuatan yang dimiliki Industri kecil bakso di Kecamatan Loceret Kabupaten Nganjuk.dapat mengatasi kelemahan dengan cukup baik, seperti telihat pada Tabel 4 di bawah ini.

Tabel 4. Faktor-faktor Internal Industri Bakso

\begin{tabular}{|c|c|c|c|}
\hline Faktor Internal & Bobot & $\begin{array}{c}\mathrm{Ra} \\
\text { ting }\end{array}$ & $\begin{array}{l}\text { Bobot } x \\
\text { Rating }\end{array}$ \\
\hline \multicolumn{4}{|l|}{ Kekuatan } \\
\hline - Pengalaman produksi & 0,1078 & 3 & 0,3235 \\
\hline - Memiliki mesin pengolah & 0,1109 & 3 & 0,3328 \\
\hline $\begin{array}{l}\text { bakso dagıng } \\
\text { - Kontinuitas produksi }\end{array}$ & 0,1038 & 4 & 0,4153 \\
\hline $\begin{array}{l}\text { terjamin } \\
\text { - Kemasan yang higienis dan }\end{array}$ & 0,1139 & 4 & 0,4557 \\
\hline cukup menarik & & 4 & 04178 \\
\hline daging yang tahan lama & & & \\
\hline - Target pasar untuk semua & 0,0 & 3 & 0,2248 \\
\hline $\begin{array}{l}\text { - Harga jual yang cukup } \\
\text { terjangkau }\end{array}$ & 0,1192 & 3 & 0,3576 \\
\hline \multicolumn{4}{|l|}{ Kelemahan } \\
\hline $\begin{array}{l}\text { - Tenaga pemasaran yang } \\
\text { masih kurang }\end{array}$ & 0,0828 & 2 & 0,1655 \\
\hline - Promosi belum maksimal & 0,0671 & 1 & 0,0671 \\
\hline - Sarana transportasi kurang & 0,0549 & 2 & 0,1098 \\
\hline $\begin{array}{l}\text { - Jangkauan pemasaran } \\
\text { belum optimal }\end{array}$ & 0,0602 & 1 & 0,0602 \\
\hline Total & 1,0000 & & 2,9300 \\
\hline
\end{tabular}

Sumber : Analisis data primer
Berdasarkan Tabel 4 tersebut diketahui skor tertinggi pada faktor kekuatan adalah pada kemasan yang higienis dan cukup menarik, Skor terendah pada faktor kekuatan adalah target pasar untuk semua golongan usia. Sedangkan pada faktor kelemahan, skor tertinggi adalah tenaga pemasaran yang masih kurang. Skor terendah adalah jangkauan pemasaran belum optimal.

\section{Eksternal Faktor Evaluation Matrix (Matriks EFE)}

Hasil Matriks IFE menunjukkan bahwa menunjukkan bahwa Industri kecil bakso di Kecamatan Loceret Kabupaten Nganjuk.cukup baik dalam merespon peluang dan meminimalisasi ancaman seperti telihat pada Tabel 5 di bawah ini.

Tabel 5. Faktor-faktor Eksternal Industri Bakso

\begin{tabular}{|c|c|c|c|}
\hline Faktor Eksternal & Bobot & $\begin{array}{c}\text { Ra } \\
\text { ting }\end{array}$ & $\begin{array}{l}\text { Bobot } x \\
\text { Rating }\end{array}$ \\
\hline \multicolumn{4}{|l|}{ Peluang } \\
\hline - Kontinuitas bahan baku & 0,1505 & 3 & 0,4514 \\
\hline $\begin{array}{l}\text { terjamin } \\
\text { - Adanya kepercayaan } \\
\text { konsumen }\end{array}$ & 0,1255 & 3 & 0,3764 \\
\hline - Konsumen dari peserta & 0,1547 & 3 & 0,4642 \\
\hline $\begin{array}{l}\text { - Pedagang pengecer } \\
\text { membantu memperluas }\end{array}$ & 0,1041 & 3 & 0,3124 \\
\hline pasar & & & \\
\hline $\begin{array}{l}\text { - Adanya pameran yang } \\
\text { diadakan pemerintah }\end{array}$ & 0,0757 & 2 & 0,1514 \\
\hline - Kondisi ekonomi yang stabil & 910 & 2 & 0,1820 \\
\hline \multicolumn{4}{|l|}{ Ancaman } \\
\hline \multirow{2}{*}{$\begin{array}{l}\text { - Semakin banyak produk } \\
\text { bakso tanpa merk } \\
\text { dipasaran } \\
\text { - Merek produk pesaing yang } \\
\text { sudah terkenal }\end{array}$} & 0,1519 & 3 & 0,4557 \\
\hline & 0,1466 & 2 & 0,2932 \\
\hline Total & 1,0000 & & 2,6867 \\
\hline
\end{tabular}

Sumber : Analisis data primer

Dari Tabel 5 tersebut diketahui skor tertinggi pada peluang adalah adanya konsumen dari peserta pelatihan yang diadakan perusahaan. Skor terendah pada peluang adalah adanya pameran yang diadakan pemerintah. Sedangkan pada ancaman, skor tertinggi terdapat pada semakin banyak produk bakso tanpa merk di pasaran. Skor terendah pada merek produk pesaing yang sudah terkenal. 
Berdasar analisis total Matriks IFE sebesar 2,93 dan total Matriks EFE sebesar 2,69, maka kemudian dipetakan dalam Matriks IE, sehingga diketahui posisi perusahaan, seperti terlihar dalam Gambar 1 di bawah ini.

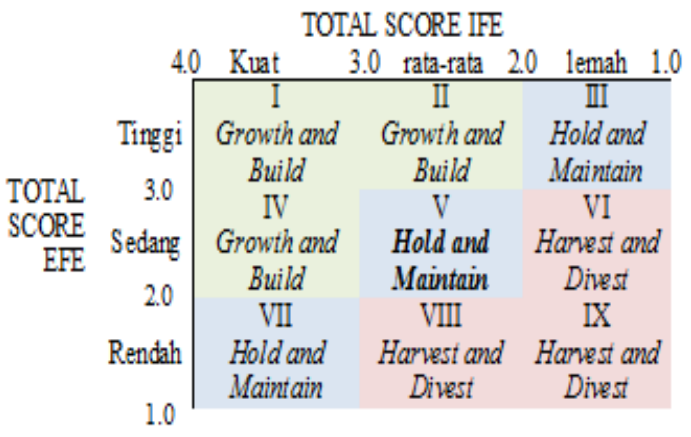

Gambar 1. Total nilai Matriks IE pada perusahaan Industri kecil bakso di Kecamatan L oceret Kabupaten Nganjuk.
Dari Gambar 1 tersebut dapat diketahui bahwa Industri kecil bakso di Kecamatan Loceret Kabupaten Nganjuk.berada pada daerah $\mathrm{V}$ yaitu Hold And Maintain, hal ini berarti Industri kecil bakso di Kecamatan Loceret Kabupaten Nganjuk .memiliki peluang untuk terus dipertahankan dan terus dipelihara. Strategi yang cocok untuk daerah ini adalah penetrasi pasar dan pengembangan produk.

\section{Analisis Matriks SWOT}

Hasil analisis Matriks SWOT pengembangan usaha di Industri kecil bakso di Kecamatan Loceret Kabupaten Nganjuk.dapat dilihatpada Tabel 6 dibawah ini.

Tabel Matriks SWOT Pengembangan usaha Bakso pada Industri kecil bakso di Kecamatan Loceret Kabupaten Nganjuk

\begin{tabular}{|c|c|c|}
\hline & Kekuatan/ Strength & Kelemahan/Weaknesses \\
\hline & $\begin{array}{l}\text { - Pengalaman produksi } \\
\text { perusahaan } \\
\text { - Memiliki mesin pengolah } \\
\text { bakso daging } \\
\text { - Kontinuitas produksi terjamin } \\
\text { - Kemasan yang higienis dan } \\
\text { cukup menarik } \\
\text { - Daya simpan produk bakso } \\
\text { daging yang tahan lama } \\
\text { - Target pasar untuk semua } \\
\text { golongan usia } \\
\text { - Harga jual yang cukup } \\
\text { terjangkau }\end{array}$ & $\begin{array}{l}\text { - Tenaga pemasaran yang } \\
\text { masih kurang } \\
\text { - Promosi belum } \\
\text { maksimal } \\
\text { - Sarana transportasi } \\
\text { kurang } \\
\text { - Jangkauan pemasaran } \\
\text { belum optimal }\end{array}$ \\
\hline Peluang/ Opportunity & Strategi S-O & Strategi W-O \\
\hline $\begin{array}{l}\text { - Kontinuitas bahan baku } \\
\text { terjamin } \\
\text { - Adanya kepercayaan } \\
\text { konsumen } \\
\text { - Konsumen dari peserta } \\
\text { pelatihan/ magang } \\
\text { - Pedagang pengecer } \\
\text { membantu memperluas } \\
\text { pasar } \\
\text { - Adanya pameran yang } \\
\text { diadakan pemerintah } \\
\text { - Kondisi ekonomi yang } \\
\text { stabil }\end{array}$ & $\begin{array}{l}\text { - Peningkatan efisiensi } \\
\text { pemakaian mesin untuk } \\
\text { memaksimalkan volume } \\
\text { produksi (S1, S2, S3, O1, } \\
\text { O3) } \\
\text { - Pembukaan cabang dan } \\
\text { jaringan distribusi untuk } \\
\text { memperluas jangkauan } \\
\text { pemasaran (S6, S7, O4, O6) } \\
\text { - Pengenalan produk ke } \\
\text { masyarakat dengan lebih } \\
\text { aktif mengikuti pameran (S6, } \\
\text { S7, O5) }\end{array}$ & $\begin{array}{l}\text { - Pemanfaatan media } \\
\text { internet untuk promosi } \\
\text { dan menjalin interaksi } \\
\text { dengan konsumen (W2, } \\
\text { W4, O2, O3) } \\
\text { - Penjajakan daerah } \\
\text { pemasaran baru yang } \\
\text { memiliki potensi } \\
\text { terhadap peningkatan } \\
\text { penjualan produk (W1, } \\
\text { W3, W4, O4) }\end{array}$ \\
\hline Ancaman/ Threats & Strategi S-T & Strategi W-T \\
\hline
\end{tabular}




\begin{tabular}{|c|c|c|}
\hline $\begin{array}{l}\text { - Semakin banyak produk } \\
\text { bakso tanpa merk } \\
\text { dipasaran } \\
\text { - Merek produk pesaing } \\
\text { yang sudah terkenal }\end{array}$ & $\begin{array}{l}\text { - Mempertahankan harga dan } \\
\text { meningkatkan kualitas } \\
\text { produk (S4, S5, S7, T1, T2) }\end{array}$ & $\begin{array}{l}\text { - Perekrutan tenaga } \\
\text { pemasaran dan } \\
\text { menambah sarana } \\
\text { transportasi untuk meng- } \\
\text { hadapi pesaing dan } \\
\text { memperluas pasar (W1, } \\
\text { W3, W4, T2) }\end{array}$ \\
\hline
\end{tabular}

Sumber : Analisis data primer

Penentuan Faktor Strategis dengan Matriks QSP

Dari hasil analisis Matriks Internal Eksternal dan Matriks SWOT, diperoleh alternatif strategi yang akan diterapkan bagi Industri kecil bakso di Kecamatan Loceret Kabupaten Nganjuk.

Secara rinci penentuan strategi tersebut dapat dilihat pada Tabel di bawah ini :

Tabel Matriks QSP Pengembangan Usaha pada Industri kecil bakso di Kecamatan Loceret Kabupaten Nganjuk.

\begin{tabular}{|c|c|c|c|c|c|c|c|}
\hline \multirow{3}{*}{\begin{tabular}{|c|} 
\\
Faktor Internal \\
\end{tabular}} & \multirow{3}{*}{ Bobot } & \multicolumn{6}{|c|}{ Alternatif Strategi } \\
\hline & & \multicolumn{2}{|r|}{$\mathrm{I}$} & \multicolumn{2}{|r|}{ II } & \multicolumn{2}{|r|}{ III } \\
\hline & & AS & TAS & AS & TAS & AS & TAS \\
\hline \multicolumn{8}{|l|}{ Kekuatan } \\
\hline o Pengalaman produksi perusahaan & 0,1078 & 4 & 0,4313 & 2 & 0,2156 & 3 & 0,3235 \\
\hline o Memiliki mesin pengolah bakso daging & & 3 & 0,3328 & 2 & 0,2219 & 4 & 0,4437 \\
\hline o Kontinuitas produksi terjamin & & 4 & 0,4153 & 2 & 0,2077 & 3 & 0,3115 \\
\hline $\begin{array}{l}\text { Kemasan yang higienis dan cukup } \\
\text { menarik }\end{array}$ & 0,1139 & 3 & 0,3418 & 4 & 0,4557 & 2 & 0,2279 \\
\hline $\begin{array}{l}\text { Daya simpan produk bakso daging yg } \\
\text { tahan lama }\end{array}$ & 0,1044 & 3 & 0,3133 & 2 & 0,2089 & 4 & 0,4178 \\
\hline o Target pasar untuk semua golongan usia & 0 & 3 & 0,2248 & 4 & 0,2997 & 2 & 0,1499 \\
\hline 0 Harg & & 2 & 0,2384 & 4 & 0,4769 & 3 & 0,3576 \\
\hline \multicolumn{8}{|l|}{\begin{tabular}{|l} 
Kelemahan \\
\end{tabular}} \\
\hline a pemasaran & & 3 & 0,2483 & 2 & 0,1655 & 1 & 0,0828 \\
\hline belum maksimal & & 3 & 0,2012 & 4 & 0,2682 & 2 & 0,1341 \\
\hline ansportasi kurang & & 1 & 0,0549 & 2 & 0,1098 & 3 & 0,1647 \\
\hline o Jangkauan pema & & 2 & 0,1204 & 3 & 0,1806 & 1 & 0,0602 \\
\hline Total bobot & & & & & & & \\
\hline \multicolumn{8}{|l|}{ Faktor Eksternal } \\
\hline \multicolumn{8}{|l|}{ Peluang } \\
\hline o Kontinuitas bahan & & 3 & 0,4514 & 2 & 0,3009 & 4 & 0,6018 \\
\hline o Adanya kepercayaa & & 2 & 0,2509 & 3 & 0,3764 & 4 & 0,5018 \\
\hline $\begin{array}{l}\text { Konsumen dari peserta pelatihan atau } \\
\text { magang }\end{array}$ & 0,1547 & 4 & 190 & 3 & 0,4642 & 2 & 0,3095 \\
\hline \begin{tabular}{|l} 
Pedagang pengecer membantu \\
memperluas pasar
\end{tabular} & 0,1041 & 3 & 0,3124 & 2 & 0,2082 & 1 & 0,1041 \\
\hline $\begin{array}{l}\text { Adanya pameran yang diadakan } \\
\text { pemerintah }\end{array}$ & 0,0757 & 1 & 0,0757 & 3 & 0,2271 & 2 & 0,1514 \\
\hline o Kondisi ekonomi yang stabil & 0 & 2 & 0,1820 & 3 & 0,2731 & 1 & 0,0910 \\
\hline \multicolumn{8}{|l|}{ Ancaman } \\
\hline $\begin{array}{l}\text { Semakin banyak produk tanpa merk di } \\
\text { pasaran }\end{array}$ & 0,1519 & 3 & 0,4557 & 1 & 0,1519 & 2 & 0,3038 \\
\hline $\begin{array}{l}\text { Merek produk pesaing yang sudah } \\
\text { terkenal }\end{array}$ & 0,1466 & 1 & 0,1466 & 3 & 0,4398 & 2 & 0,2932 \\
\hline Total bobot & 0000 & & & & & & \\
\hline
\end{tabular}




\begin{tabular}{|l|l|r|r|r|}
\hline Jumlah Total Nilai Daya Tarik & & 5,4161 & 5,2521 & 5,0302 \\
\hline
\end{tabular}

Sumber : Analisis data primer

Berdasar hasil perhitungan matriks QSP tersebut maka, Prioritas alternatif strategi pengembangan bisnis yang dapat diterapkan antara lain : (1) Pembukaan cabang dan jaringan distribusi untuk memperluas jangkauan pemasaran $(5,4161)$. (2) Pemanfaatan media internet untuk promosi dan menjalin interaksi dengan konsumen $(5,2521)$ dan (3) Mempertahankan harga dan meningkatkan kualitas produk $(5,0302)$. Berdasarkan ketiga alternatif strategi yang diperoleh dalam penelitian ini, prioritas strategi yang terbaik adalah strategi 1, yaitu pembukaan cabang dan jaringan distribusi untuk memperluas jangkauan pemasaran, dengan nilai TAS (Total Atractive Score) sebesar 5,4161.

\section{Kesimpulan}

Berdasarkan hasil penelitian dan pembahasan pada industri kecil bakso di Kecamatan Loceret Kabupaten Nganjuk, maka dapat ditarik kesimpulan sebagai berikut :

1. Strategi produksi industri kecil bakso yaitu dengan cara bahan baku yang berkualitas sedang karena untuk meminimalisir biaya produksi dan lebih mengutamakan ciri khas dan cita rasa dari masing - masing pedagang bakso.

2. Strategi pemasaran yang dapat dilakukan para pedagang bakso dalam memasarkan usahanya yaitu peningkatan pesanan di waktu tertentu dibarengi dengan menunjukkan ciri khas produk /merek dagang, memanfaatkan peluang pemasaran yaitu kerja sama dengan angkatan kerja muda yang merantau ke luar kota.

3. Strategi SDM (Tenaga Kerja) yang diterapkan dalam industri bakso yaitu adanya pengaktifan kembali paguyuban pedagang bakso Kecamatan Loceret Kabupaten Nganjuk yang berguna sebagai tenpat saling bertukar informasi antara pedagang satu dengan lainnya, pemberian upah tambahan bagi tenaga kerja (tenaga kerja tetap) yang giat bekerja.
4. Strategi permodalan yang dilakukan industri bakso yaitu modal awal berasal dari modal sendiri dan keuntungan dari penjualan yang diperoleh sebagai akumulasi modal; biaya upah tenaga kerja berbeda sesuai dengan pembagian tugas masing-masing; tambahan modal terjadi ketika mendapat pesanan dan menjelang hari raya; kurangnya kesaran akan pentingnya pembukuan terhadap administrasi dan keuangan

\section{Saran}

Saran yang dapat disampaikan dalam penelitian ini adalah sebagai berikut :

1. Bagi pemerintah dan pedagang sebaiknya bersama-sama terlebih dahulu memperbaiki SDM, kemudian pengembangan teknologi tanpa mengesampingkan pemasaran dan permodalan pada industri kecil bakso di Kecamatan Loceret Kabupaten Nganjuk. Karena pada dasarnya antara SDM, teknologi, pemasaran dan permodalan merupakan faktor- faktor penting dalam suatu keberlangsungan usaha.

2. Promosi produk industri bakso Kecamatan Loceret Kabupaten Nganjuk masih perlu ditingkatkan agar pasar dapat lebih diperluas dan semakin banyak konsumen yang tertarik. Caranya dapat dengan memperluas media pemasaran melalui media cetak seperti penyebaran brosur dan memasangkan spanduk. Atau dapat juga dengan cara menjalin kerja sama yang baik dengan restaurant atau rumah makan.

3. Dukungan pemerintah sangat bermanfaat bagi industri kecil hendaknya dukungan pemerintah juga diberikan kepada industri kecil bakso di Kecamatan Loceret Kabupaten Nganjuk untuk mengatasi keterbatasan modal, peralatan dalam aplikasinya pemerintah dapat memberikan informasi kepada pengusaha dalam hal pemberian modal beserta cara maupun syarat untuk 
mendapatkannya, agar dapat meningkatkan kualitas dan ciri khas produk, menghadapi ancaman persaingan dengan industri bakso dari wilayah lain dan meningkatkan promosi. Caranya dengan pemberian bantuan baik modal dan peralatan, mengadakan pelatihan produksi untuk meningkatkan kualitas produk, serta mengikuti festival - festival makanan sebagai salah satu media promosi.

4. Pemerintah setempat dan pedagang lebih bekerjasama dan saling tukar informasi yang lebih dekat dan menyeluruh dalam melakukan pendidikan, dan pelatihan bagi tenaga kerja yang masih kurang pengalaman dan kurang trampil dalam industri bakso Kecamatan Loceret Kabupaten Nganjuk sehingga dapat dikelola dengan lebih baik dan dapat mencapai pemasaran nasional dan internasional.

\section{Daftar Pustaka}

Anonim $^{a}$, 2008. Majalah Peternakan Indonesia No. 101. Dirjen Peternakan, Jakarta

Anonimb ${ }^{b}$ 2009. Majalah Peternakan Indonesia No. 195. Dirjen Peternakan, Jakarta

Anonim, 2009 ${ }^{c}$. Pengertian Usaha Kecil dan https://id.wikipedia.org/wiki/ Usaha_Kecil dan Menengah)

Anoraga, Pandji. 2011. Pengantar Bisnis: Pengelolaan Bisnis Dalam Era Globalisasi.Jakarta: Rineka Cipta

Asrulsani, 2008. Definisi Pemasaran (Marketing Definition). http://rumahbisnis. wordpress.com/2008/03/09/definisi -pemasaran-marketing-definition. Diakses pada 24 Agustus 2014

Astuti, 2007. Strategi Pemasaran Jahe (Zingiber officinale roce di Kabupaten Malang. Skripsi. Fakultas Pertanian Universitas Brawijaya Malang.

Butterfly. 2007. Strategi Pemasaran Jasa. http://rienzumaroh16.blogspot.com/ 2008/06/strategi-pemasaranjasa.html. Diakses pada 6 Agustus 2014.

Dumairy, 1996. Perekonomian Indonesia. Jakarta: Erlangga.
David. 2012. Manajemen Strategis. PT. Indeks kelompok Gramedia, Jakarta

Gilarso, T. 1992. Ekonomi Pembangunan. Jakarta : Gramedia

Hartono, B., Wisapti Ningsih, U. dan Septiarini, N. F. 2011. Perilaku Konsumen Dalam Pembelian Bakso Di Malang. Buletin Peternakan Vol. 35(2): 137-142, Juni 2011

Hidayat. 2008. Panduan Praktis Memilih Daging Sapi. PT Gramedia Pustaka Utama, Jakarta.

Ilamanoz. 2008. Strategi Pemasaran dan Pengendalian Mutu Produk. http://www.indoskripsi.com.

Diakses pada 17 Nopember 2014.

Joko Hermanianto, 2008. Teknologi Pengolahan Pangan Daging. IPB Press.Bogor

Junaidi, 2009. Proses dan Teknologi Pangan. Penerbit Alfabeta. Bandung.

Kementrian Koperasi dan Usaha Kecil Menengah tentang Usaha Kecil Menengah. Diunduh pada 20 Februari 2015 dari http://www.depkop.go.id/

Kotler, Philip.Keller, K.L.2009.Manajemen Pemasaran. Jilid I. Edisi 13. Jakarta: Erlangga

Lhatoif, Khosan.2011.Analisis Kelayakan usaha dan strategi pengembangan usaha budi daya lele di Kecamatan Sidorejo Kota Salatiga. Skripsi mahasiswa Jurusan Ekonomi Pembangunan FE Universitas Negeri Semarang.

Murtidjo. B. A. 2003. Pemotongan Dan Penanganan Daging Ayam. Penerbit Kanisius. Yogyakarta

Pujiyanto. 2003. Strategi Pemasaran Produk Melalui Media Periklanan. Skripsi. Fakultas Ekonomi Universitas Sebelas Maret Surakarta

Rahmana Arief, Yani Iriani, Rienna Oktarina. 2012." Strategi Pengembangan Usaha Kecil Menengah Sektor Industri Pengolahan". Dalam Jurnal Teknik Industri, Hal 14-21 Bandung: Universitas Widyatama Bandung 
Rangkuti. F, 2011. Analisis SWOT Teknik membedah kasus bisnis : Reorientasi konsep perencanaan strategis untuk menghadapi abad 21. PT Gramedia Pustaka Utama, Jakarta.

Rindrayani, S. R dan Astiham, B. 2011. Pengaruh Penerapan Strategi Pemasaran terhadap Perkembangan Usaha Industri Kerajinan Mamer/Onyx di Kecamatan Campurdarat Kabupaten Tulungagung. Jurnal Manajemen Pemasaran Petra Vol. 2, No. 1, (2013) 1-15.

Rineka Cipta Arikunto, Suharsimi. 2010. Prosedur Penelitian Suatu Pendekatan dan Praktek. Jakarta : Rineka Cipta. Badan Pusat Statistik (BPS). tentang Usaha Kecil Menengah

Robi Kumala Ilma.2010.Analisis Kelayakan usaha dan Strategi pengembangan industri kecil Genteng Press di desa Ngetuk Kabupaten Kudus. Skripsi mahasiswa Jurusan Ekonomi Pembangunan FE Universitas Negeri Semarang.

Salusu. 2003. Teori dan Penyelesaian Kalkulus Lanjutan

Soleh, 2010. Ilmu Pengetahuan Bahan Pangan. Penerbit Alfabeta. Bandung

Sugiyono. 2012.. Memahami Penelitian Kualitatif. Bandung: ALFABETA

Suharsimi. 2010. Prosedur Penelitian Suatu Pendekatan dan Praktek. Jakarta : Rineka Cipta.

Sukirno, Sadono. 1985. Ekonomi Pembangunan, proses, masalah, dan dan kebijakan. Jakarta : Bima Grafika

Suparmoko, 2009. Metodologi Penelitian, Aplikasi dalam Pemasaran, PT. Gramedia Pustaka Utama, Jakarta.

Tjiptono, F., 2007. Strategi Pemasaran, Edisi Kedua, Penerbit Andi-Offset, Yogyakarta.

Todaro dan Smith. 2004. Pembangunan Ekonomi di Dunia Ketiga. Edisi Kedelapan. Jakarta: Erlangga.

Tri Wahyuniarso. 2013. Strategi pengembangan industri kecil keripik di dusun karangbolo desa lerep kabupaten semarang. Skripsi mahasiswa Jurusan Ekonomi Pembangunan FE Universitas Negeri Semarang.

Undang-Undang Republik Indonesia Nomor 20 Tahun 2008 tentang Usaha Mikro, Kecil, dan Menengah (UMKM), Diunduh pada 20 Februari 2015 dari http://www.indonesia.go.id.

Website BPS: http://www.bps.go.id. Diunduh pada 20 Februari 2015. 